\title{
Socioeconomic impact of small-scale irrigation on household's livelihood improvement in Bena-Tsemay district of South Omo zone, Southern Ethiopia
}

\author{
A. Asmera*iD and A. Yidnekachew
}

Received 31 October 2021, Revised 25 November 2021, Accepted 20 December 2021, Published online 31 December 2021

\section{A B S T R A C T}

The study investigated the socioeconomic impacts of irrigated agriculture and factors affecting the decision of agro-pastoralists to participate in irrigation during 2017-2018. The result depends on cross-sectional data collected from a sample of 120 households of which 90 irrigation users and 30 non-users using a combination of purposive and random sampling. The data were analyzed using descriptive statistics and logistic regression to assess factors that affect participation in irrigation. The logistic regression model revealed that age, credit access, extension contact, distance to water, and labor force significantly affected the decision of given agro-pastoralists to participate in irrigation practices at less than $5 \%$ probability levels. This indicates that the explanatory variables included in the model influence the decision of agro-pastoralists to participate in irrigation practices. Therefore, the provision of credit service to allow rapid progress in introducing technologies like tractors for farming practices and frequent extension contact with irrigation users could enhance the productivity in the area.

Keywords: Bena-Tsemay, Livelihood, Logistic Regression and Irrigation

Southern Agricultural Research Institute, Jinka Agricultural Research Center, Directorate of Agricultural Economics and Gender Research, P.O. Box 96, Jinka, Ethiopia

*Corresponding author's email: asmera05@gmail.com (A. Asmera)

Cite this article as Asmera, A. and Yidnekachew, A. 2021. Socioeconomic impact of small-scale irrigation on household's livelihood improvement in Bena-Tsemay district of South Omo zone, Southern Ethiopia. Int. J. Agril. Res. Innov. Tech. 11(2): 139-146. https://doi.org/10.3329/ijarit.v11i2.57267

\section{Introduction}

Agriculture is the backbone of the Ethiopian economy that it contributes $70.0 \%$ of export earnings, $73.0 \%$ of employment, and $38.8 \%$ of the country's gross domestic product (UNDP, 2016). However, Ethiopian agriculture is largely small-scale, subsistence-oriented, decisively dependent on rainfall, and highly vulnerable to drought (Bewket, 2007). To overcome this problem, it is important to expand irrigation farming to supplement rain-fed agriculture. Irrigation farming increases the income of smallholder farmers at a household level, reduces the vulnerability of farmers to rainfall variability, and strengthens collective action for broader land and water management (Amede and Haileslassie, 2011; MoA, 2011). Ethiopia is endowed with plentiful water resources with 12 river basins that provide an estimated annual runoff of 125 billion m3 and 22 natural and artificial lakes, and the groundwater potential of 13.5 billion $\mathrm{m}^{3}$ per year that the country has the potential of irrigating 5.3 million hectares (Awulachew and Ayana, 2011; Makombe et al., 2011).

However, currently in Ethiopia only 640,000 ha $(5 \%)$, which includes 128,000 ha from rainwater harvesting, 383,000 ha from small-scale irrigation, and 129,000 ha from medium and large-scale irrigation of cultivable land is irrigated (Awulachew et al., 2010). Development of irrigation has been facing gaps between intended potential and actual area irrigated in the country. However, the use of small-scale irrigation increased the income of smallholder farmers in the Northern part of Ethiopia and the Fentalle agro-pastoral district of the Oromia region (Gebrehiwot et al., 2017; Regassa, 2015). Benatsemay district is one of the arid and semiarid pastoral and agro-pastoral districts of South nation nationality and peoples region with a total area of 21,908 ha. The district has the potential of irrigating 6042 ha and irrigation schemes having different capacities had been constructed by the government and are already functional to supplement the rain-fed agricultural practices of the area. The scheme has been established to improve the income and livelihood of agropastoralists and there are some improvements in the livelihood of the agro-pastoralists in the area. The study by Asmera and Melkamu (2020) indicated that water harvesting is important in securing food supply and generating income for their family through using irrigation and also good means of tackling the impacts of drought in the Bena-Tsemay district. Coping mechanisms of pastoralists and agro-pastoralists in arid and 
semi-arid areas are so fragile that minor change in rainfall distribution often results in famine (OIDA, 2004; García-Bolanos et al., 2011).

In the study district, some agro-pastoralists are not willing to participate in the irrigation practices and they are not benefited from implemented strategies and are dependent on aid from the government and NGOs. To date, there is no empirically analyzed information about the positive and negative impacts of the irrigation schemes on household livelihood improvement in the study district. Seleshi et al. (2005) indicated the need for undertaking impact assessment of small-scale irrigation particularly on production and productivity of rural households. Therefore, this activity was initiated with the main objective of analyzing the socioeconomic impacts of irrigated agriculture and factors affecting the decision of a given agro-pastoralists to participate in irrigation practices.

\section{Materials and Methods}

Data collection: The data used for this study were essentially from primary sources. The data were collected from 120 agro-pastoralists on whom well-structured personal interview schedules were administered in the Bena-Tsemay district of South nation nationalities and peoples region of Ethiopia in 2017. The purposive sampling technique was used in selecting the users and non-user agro-pastoralists of irrigation to see the income differences of the households. Ninety users and thirty non-user agropastoralists were randomly selected from each kebele's making a total of 120 respondents.

Data analysis: Descriptive statistics and econometric models were used to describe variables and study the relationships between variables empirically. Mean, standard deviation, frequency distribution, and percentage were used to examine the socio-economic conditions of the sample respondents by comparing irrigation users and non-users. On the other hand, the econometric model used was the logit model. This study identified the dependent variable as a user of a small-scale irrigation scheme or not. The functional form of the logit model is specified as follows, Gujarati (2003):

Household is a user of irrigation schemes or not $(\mathrm{Y})=\alpha \mathrm{O}+\beta 1 \mathrm{Age}+\beta 2 \mathrm{Education}+\beta 3$ Farm size $+\beta 4$ Nonfarm income $+\beta 5$ Extension contact $+\beta 6$ Credit access $+\beta 7$ Livestock holding $+\beta 8$ Farm size $+\beta$ gDistance to water $+\mathrm{e}($ error term) Where $\alpha$ is intercept and $\beta 1, \quad \beta 2, \ldots \ldots \ldots . . \beta \mathrm{n}$ are slope coefficients of the explanatory variables in the model.

\section{Results and Discussion}

The socio-economic characteristics of the respondents were summarized in Table 1 . The mean ages of sample household heads of user and non-users of irrigation were 37.80 and 38.37 with a standard deviation of 8.58 and 8.03 years, respectively. The mean available labour in man equivalent for the user and non-user households was found to be 4.02 and 3.70 with a standard deviation of 2.47 and 2.12, respectively. User agro-pastoralists have relatively larger labor units in man equivalent when compared with nonusers households, which may indicate that labor availability is a key component to be considered for participation decision. This means that to undertake irrigation works households need to have enough labor. The mean education level of users and non-users were grade 1 and illiterate, respectively. This indicates that irrigation user households are more educated than non-users. Distance to a water source also matters to participate in irrigation practices. The minimum and maximum time required to arrive at the nearest water source were 10 minutes and 2 to 5 hours (during dry seasons), respectively. On average, willing pastoralists or agro-pastoralist walks for 43.48 minutes while the figure was 20 minutes for the non-willing pastoralist or agropastoralists. The land size holding of the sample agro-pastoralist ranges from 0.50 to 5.00 hectares. The average landholding of the total sample household heads was 3.22 ha with an average size of 3.24 and 2.96 ha for willing and non-willing participant household heads of water harvesting activities, respectively.

Table 1. Socio-economic characteristics of the respondents.

\begin{tabular}{|l|llll|}
\hline Users of irrigation(90) & Minimum & Maximum & Mean & Std. Deviation \\
\hline Age of respondent(year) & $\mathbf{2 1 . 0 0}$ & 60.00 & 37.80 & 8.579 \\
\hline Active labour force(man equivalent) & 1.00 & 14.00 & 4.02 & 2.47 \\
\hline Education level(grade) & 0.00 & 9.00 & 0.66 & 1.51 \\
\hline Total irrigated land(ha) & 0.50 & 5.00 & 1.09 & 0.83 \\
\hline Distance to irrigation water (km) & 2.00 & 9.00 & 4.27 & 1.59 \\
\hline Non-users of irrigation(30) & & & & \\
\hline Age of respondent(year) & 25.00 & 60.00 & 38.37 & 8.03 \\
\hline Active labour force(man equivalent) & 1.00 & 10.00 & 3.70 & 2.12 \\
\hline Education level(grade) & 0.00 & 5.00 & 0.37 & 5.00 \\
\hline Distance to water source(km) & 3.00 & 35.00 & 19.83 & 9.27 \\
\hline Total non-irrigated land(ha) & 0.25 & 1.25 & 0.66 & 0.26 \\
\hline
\end{tabular}

Source: Own survey, 2017/18 


\section{Crop yields of selected major food crops in users and non-user areas of small scale irrigation}

The major type of crops cultivated in the study areas of the district are maize, sorghum, and sesame, and agro-pastoralists produce crops for home consumption, income generation and as a seed for further production. Sorghum, maize, finger millet, and teff are also the main crops grown in the Benatsemay district (Terefe et al., 2010). Table 2 below shows the trend of estimated crop yields of selected major foods over three consecutive years in user and non-user areas of irrigation. The estimated sorghum crop yields under irrigation and non-irrigation in the years 2015 were 0.30 ton $\mathrm{ha}^{-1}$ and 0.14 ton ha-1, respectively. It shows that there is about a $53.33 \%$ yield increment under irrigation. Whereas the estimated yield of maize crop at the same year was 0.59 ton $\mathrm{ha}^{-1}$ and 0.24 ton haunder irrigation and non-irrigation, respectively, and showed about $59.30 \%$ yield increment under irrigation. Similarly, in the year 2017, the estimated sorghum crop yields under irrigation and non-irrigation were 0.35 ton $\mathrm{ha}^{-1}$ and 0.19 ton ha-1 respectively. It shows that there is about a $45.70 \%$ yield increment under irrigation. On the other hand, the estimated yield of maize crop in the year 2017 was 0.74 ton ha-1 and 0.32 ton ha $^{-1}$ under irrigation and non-irrigation respectively, and showed about $56.76 \%$ yield increment under irrigation. An impact evaluation of international fund for agricultural development small scale irrigation in four administrative regions of Ethiopia, namely Tigray, Southern regions, Oromia, and Amhara, showed that in about 60 percent of the schemes crop yield under irrigation was higher by at least 35 percent compared with non-irrigated farms (Amede, 2006). The average income of irrigation users was $52 \%$ higher than non-irrigation users (Astatike, 2016).

Table 2. Trends of estimated crop yields of selected major food crops in users and non-user areas of irrigation.

\begin{tabular}{|c|c|c|c|c|c|c|}
\hline $\begin{array}{l}\text { Sample } \\
\text { households(120) }\end{array}$ & Major crops & Year & Minimum & Maximum & Mean & $\begin{array}{l}\text { Std. } \\
\text { Deviation }\end{array}$ \\
\hline \multirow{9}{*}{ Users(90) } & \multirow{3}{*}{$\begin{array}{l}\text { Sorghum yield } \\
\left(\text { ton ha-1) }^{-1}\right.\end{array}$} & 2015 & 0.02 & 0.80 & 0.30 & 0.18 \\
\hline & & 2016 & 0.01 & 0.10 & 0.34 & 0.18 \\
\hline & & 2017 & 0.01 & 0.10 & 0.35 & 0.17 \\
\hline & \multirow{3}{*}{$\begin{array}{l}\text { Maize yield } \\
\left(\text { ton ha-1) }^{-1}\right)\end{array}$} & 2015 & 0.10 & 0.27 & 0.59 & 0.42 \\
\hline & & 2016 & 0.15 & 0.20 & 0.73 & 0.48 \\
\hline & & 2017 & 0.10 & 0.20 & 0.74 & 0.42 \\
\hline & \multirow{3}{*}{$\begin{array}{l}\begin{array}{l}\text { Sesame } \\
\left(\text { ton } h^{-1}\right)\end{array} \\
\text { yield }\end{array}$} & 2015 & 0.01 & 0.70 & 0.29 & 0.16 \\
\hline & & 2016 & 0.01 & 0.10 & 0.35 & 0.19 \\
\hline & & 2017 & 0.01 & 0.10 & 0.36 & 0.19 \\
\hline \multirow{6}{*}{ Non users(30) } & \multirow{3}{*}{$\begin{array}{l}\text { Sorghum yield } \\
(\text { ton ha-1) }\end{array}$} & 2015 & 0.05 & 0.20 & 0.14 & 0.06 \\
\hline & & 2016 & 0.05 & 0.30 & 0.19 & 0.08 \\
\hline & & 2017 & 0.05 & 0.50 & 0.19 & 0.10 \\
\hline & \multirow{3}{*}{$\begin{array}{l}\text { Maize yield } \\
\left(\text { ton }^{-1} a^{-1}\right)\end{array}$} & 2015 & 0.01 & 0.50 & 0.24 & 0.12 \\
\hline & & 2016 & 0.01 & 0.50 & 0.29 & 0.13 \\
\hline & & 2017 & 0.01 & 0.60 & 0.32 & 0.15 \\
\hline
\end{tabular}

Source: Own survey, 2017/18

\section{Household Income of users and non-users of small scale irrigation}

The estimated average annual gross income of irrigation users from sales of the crop were 6107, 8321 \& 8380 ETB and from livestock were 3178 , 4451 \& 4373 ETB in three consecutive years (2015, 2016 \& 2017), respectively. On the other hand, the estimated average annual gross income of non-irrigation users from sales of the crop were 121, 156 \& 246 ETB and from livestock were 4636,4896 \& 4956 ETB in three consecutive years (2015, 2016 \& 2017), respectively. Income from the sale of the crop for irrigation users over the years was far higher than that of non-user agro-pastoralists due to the number of cropping per year and diversification of crop production.
Irrigation increases agricultural productivity and farm income per hectare and insulates the national agricultural and economic sector against weather-related shocks and increasing agricultural yield, increasing the area of arable land and increasing cropping intensity (Nhundu et al., 2010). Farmers of Burkina Faso, Ghana, and Senegal who are involved in small-scale irrigation could obtain a 20 percent increase in crop yields, and a 15 percent increase in farm income than counterpart (Danso et al., 2003; Faruqui et al., 2004; WAIPRO, 2009). Whereas income from livestock sale of irrigation users over the years was lesser than that of non-user agropastoralists due to the agro-pastoralist behavior that they care livestock than crop production and move from place to place in search of water and 
feed. Livestock mainly production and cultivation are the basis for economic culture for the pastoral and agro-pastoral ethnic groups in Bena-Tsemay and Hamer districts (Asmera et al., 2020). However, Regassa (2015) reported opposite to this study result that access to an irrigation project in mixed farming areas gave an income advantage of $44.14 \%$ from livestock sales than non-access areas.

Table 3. Total estimated income of both irrigation users and non-users areas over three years.

\begin{tabular}{|c|c|c|c|c|c|c|c|c|}
\hline $\begin{array}{l}\text { Sample } \\
\text { households(120) }\end{array}$ & $\begin{array}{l}\text { Sources of } \\
\text { income }\end{array}$ & Year & $\mathrm{N}$ & Minimum & Maximum & Sum & Mean & $\begin{array}{l}\text { Std. } \\
\text { Deviation }\end{array}$ \\
\hline \multirow{6}{*}{ Users(90) } & \multirow{3}{*}{$\begin{array}{l}\text { Total } \\
\text { annual } \\
\text { income } \\
\text { from } \\
\text { livestock } \\
\text { sale (ETB) }\end{array}$} & 2015 & 90 & 100.00 & 16300.00 & 286030.00 & 3178.11 & 2972.92 \\
\hline & & 2016 & 90 & 300.00 & 25000.00 & 400620.00 & 4451.33 & 4070.39 \\
\hline & & 2017 & 90 & 450.00 & 25000.00 & 393590.00 & 4373.22 & 4039.83 \\
\hline & \multirow{3}{*}{$\begin{array}{l}\text { Total } \\
\text { annual } \\
\text { income } \\
\text { from crop } \\
\text { sale (ETB) }\end{array}$} & 2015 & 90 & 1000.00 & 15000.00 & 537500.00 & 6107.95 & 3526.26 \\
\hline & & 2016 & 90 & 3000.00 & 32000.00 & 732330.00 & 8321.93 & 5247.94 \\
\hline & & 2017 & 90 & 4800.00 & 32000.00 & 737480.00 & 8380.45 & 5578.21 \\
\hline \multirow[t]{6}{*}{ Non user(30) } & \multirow{3}{*}{$\begin{array}{l}\text { Total } \\
\text { annual } \\
\text { income } \\
\text { from } \\
\text { livestock } \\
\text { sale (ETB) }\end{array}$} & 2015 & 30 & 100.00 & 9000.00 & 139090.00 & 4636.33 & 2126.70 \\
\hline & & 2016 & 30 & 300.00 & 8000.00 & 146900.00 & 4896.67 & 1863.11 \\
\hline & & 2017 & 30 & 450.00 & 12000.00 & 148700.00 & 4956.67 & 2274.28 \\
\hline & \multirow{3}{*}{$\begin{array}{l}\text { Total } \\
\text { annual } \\
\text { income } \\
\text { from crop } \\
\text { sale (ETB) }\end{array}$} & 2015 & 30 & 100.00 & 800.00 & 3630.00 & 121.00 & 192.70 \\
\hline & & 2016 & 30 & 300.00 & 1200.00 & 4680.00 & 156.00 & 248.19 \\
\hline & & 2017 & 30 & 420.00 & 1200.00 & 7380.00 & 246.00 & 361.08 \\
\hline
\end{tabular}

Source: Own survey, 2017/18

Direct and indirect use, impact (positive and negative)

Livelihood improvement and Employment opportunity

As discussed in a group discussion with agropastoralists due to irrigation water use; farm income, assets of inhabitants, and their livelihood improved. Institutional improvement (social bond, social asset, and collective action) and social crisis (migration, unemployment) of the residents were decreased. Improving farming base (oriented towards cash crops like sesame and onion) and change in land use effect (substitute) not much increased. The survey result indicated that the majority (95.56\%) of the respondent engaged in mixed farming, which is crop cultivation and animal rearing whereas the remaining only $4.44 \%$ was engaged in crop cultivation, off-farm, and non-farm activities as their main livelihood in the study area. Most residents' livelihood depends on irrigation water for both crop and livestock production.

Table 4. Livelihood activity.

\begin{tabular}{|lcc|}
\hline Main livelihood activity & Frequency & Percent \\
\hline Crop cultivation & 1 & 1.11 \\
\hline Mixed farming & 86 & 95.56 \\
\hline Off-farm \& non-farm & 3 & 3.33 \\
\hline
\end{tabular}

Source: Own survey result, 2017/18
As depicted in Table 5 below, the sample respondents indicated that irrigation has brought the economic benefit $98.90 \%$ whereas only $1.10 \%$ disagrees with its contribution. On the other hand, $97.80 \%$ of respondents indicated that there is a yield change in their crop production whereas only $2.20 \%$ of the respondents did not agree with the change in grain yield due to irrigation water use. Furthermore, about $98.90 \%$ and $93.33 \%$ of sample respondents indicated a change in farm income and livelihood respectively. However, $1.10 \%$ and $6.70 \%$ of the sample respondents indicated that there is no contribution to change in farm income and livelihood improvement respectively due to irrigation use. Irrigation has also great contribution in creating employment opportunities for the agro-pastoralists in the study area. Land preparation, weeding, chemical application, watering, harvesting, and transportation require employing different labor. Therefore, irrigation has not only enhanced agricultural production and productivity but also provide employment opportunities to the agropastoralists in the study area. About $98.90 \%$ of the sample respondent indicated that the irrigation access created job opportunities for agro-pastoralists whereas only $1.10 \%$ of the respondents did not agree with it. 
Table 5. Contribution of irrigation for participant households.

\begin{tabular}{|lccc|}
\hline Contribution(90 sample HHds) & Yes/No & Frequency & Percent \\
\cline { 2 - 4 } & Yes & 89 & 98.90 \\
\hline Grain yield & No & 1 & 1.10 \\
\cline { 2 - 4 } & Yes & 88 & 97.80 \\
\hline Increased farm income & No & 2 & 2.20 \\
\cline { 2 - 4 } & Yes & 89 & 98.90 \\
\hline Increased employment opportunity & No & 1 & 1.10 \\
\cline { 2 - 4 } & Yes & 89 & 98.90 \\
\hline Improved livelihood condition & No & 1 & 1.10 \\
& Yes & 84 & 93.33 \\
\cline { 2 - 4 } & No & 6 & 6.67 \\
\hline
\end{tabular}

Source: Own survey result, 2017/18

\section{Social benefits and impacts in using irrigation water}

Intensive use of farm or land for the crop, more demand for irrigated land, more agro-pastoralists rent out land at better rent price, an inflow of newcomers to work on farms, community service (pity shop, traders, village market, schools, rural clinics) increased or changes made on and also voluntary participation (water use association, cooperatives ) have been changed.

\section{Environmental impacts (positive and negative)}

As respondents revealed that due to irrigation water use environmental contamination (groundwater and surface), crop disease (seed bug, mealy bug, and aphids), siltation, salinity, and other soil born disease, and contamination of waterways resulted in poor water quality and quantity loss beyond the command area. Concerning erosion risk, no problems exist.

\section{For non-users of irrigation water}

According to respondents, they heard about the irrigation scheme in 1993 E.C. from Omo farming development and other user agro-pastoralists. The perception level of the community towards irrigation is high but as a result of topography, they did not use irrigation activity for agriculture. The sample respondents indicated that about $33 \%$ have insufficient water for irrigation and is the limiting factor to use irrigation, $50 \%$ unsuitable land for irrigation whereas $17 \%$ was drainage limitation. As the report revealed from the focus group discussion, the factors that make the community not use irrigation were lack of available source of water, the topography of the environment, inadequate research support, inadequate water harvesting technology, and knowledge gap on users towards irrigation technology. To some extent, social and economic factors forced them not to use irrigation technology. In addition, non-users were migrated from the community to the other areas to search for water and faced with several disasters such as being unemployed, out of farming activities and most of them depending on rain-fed agriculture. According to the sample respondents, the majority (90\%) of the respondents revealed that the migration has been increased in those who did not use irrigation whereas only $10 \%$ of the respondents indicated the absence of irrigation was not the case for migration. Irrigation users have high crop productivity than non-users.

\section{The use of rainwater}

As revealed from kebele expert (DA) and some model farmers in areas with irrigation there were some environmental impacts (threats) that irrigation water imposed on land; these were soil salinity, fertility decline, and increased need for inorganic fertilizer (DAP, urea). As depicted in the above tables the sample respondents indicated that $23.30 \%$ of the sampled respondents said the use of rainwater for agriculture was the problem for soil erosion whereas $76.70 \%$ of the sample respondents did not agree with the soil erosion problem due to the use of rain-fed. However, all the sample respondents indicated that the use of rainwater did not cause soil salinity, waterlogging, and soil alkalinity problems. However, there were high social impacts due to the use of rainwater. As revealed in group discussion non-users community, need to shift from rain-fed agriculture to irrigated farms because of understanding the advantage of irrigation: constraints in using irrigation technologies; illegal acts (stealing of canal), crop pesticide and insecticide, siltation, and salinity were common problems in areas with irrigation and the same is true if we will be the user of irrigation technologies.

\section{Factors that affect the participation of agro pastoralist's decision in irrigation practice}

The result in Table 6 presented the binary logistic model analysis used to estimate the factors affecting the participation of a given agropastoralist in irrigation practice. The dependent 
variable i.e., participate/use irrigation practice is dichotomous and can be represented by dummy variables. That means 1 if they are a user or participate in irrigation practice and o if they do not. Out of the nine, explanatory variables specified in the model, 5 significantly influenced agro pastoralists' decision to participate/use the irrigation practices. The chi-square statistics are highly significant $(\mathrm{p}<0.0000)$. The explanatory power of the factors as reflected by Pseudo $\mathrm{R}^{2}$ was high (0.6415), indicating that the hypothesized variables are responsible for about $64 \%$ of the variations in decision making of agropastoralists to participate in irrigation practices.

Age of household head: is significant at less than $5 \%$ significance level and hurts participation decision of irrigation practice. The negative effect of this variable indicates that aged peoples are rarely interested to participate in irrigation practices than the younger. It means that aged household heads participate less in the agricultural wage labor force than younger, thus, aged agro-pastoralists are expected to be less participated and hence aged agro-pastoralists rely more on keeping livestock than the youngsters in the study area. Holding influences of other factors constant, as the age of household head increases by one more year, the likely probability to participate in irrigation practices decreases by a factor of 0.850 . The study by Owusu et al. (2011) and Berehanu (2007) decision to participate in irrigation farming is affected by the age square of households significantly and positively.

Credit access and use: Accessibility of credit facilities is a prerequisite for a technology to be adopted and promoted properly. It was significant at less than $1 \%$ level and positively related to participation in irrigation activities. This result agreed with what was expected earlier in the hypothesis that access to credit facilities and use relaxes financial constraints of agropastoralist to participate in any irrigation activities. The positive relationship indicates that the odds ratio in favor of the probability of participating increases with an increase in access to credit facilities and use of it. Access to credit enables smallholder farmers to purchase inputs (fertilizer, improved seed, and agrochemicals) and other production equipment's which would encourage them to produce a given cash crop like vegetables and improve the livelihood of people (Yeshambel, 2019). The odds ratio of 1.008 for credit access implies that other things being constant, the odds ratio in favor of being participant increases by a factor of 1.008 as credit access and use increases by a unit. On the other hand, participation in irrigation activities increases by a factor of 1.008 as the availability of credit access and use increases by one unit.
Labour force (man equivalent): it is significant at less than $5 \%$ and positively related with the participation in irrigation practices indicating that an increase in labour allows agropastoralists to achieve a large labour force. This result was consistent with many other research results. Asmera and Melkamu (2020) mentioned the availability of labour as an important element for the promotion of water harvesting works. With the assumption of constant influences of other factors, the odds ratio indicates that the probability of being willing to participate in irrigation work increases by a factor of 2 as labour availability increases by a one-man equivalent unit.

Access to irrigation water: This variable is significant at less than 5\% level and related positively to participation in irrigation works. The result is consistent with the idea in the hypothesis, which means those agro-pastoralists who are nearby the water source may have more access to water for their household consumption, livestock, and crop watering than those who are distant to water sources. As they are located near the water source, they are interested to participate in irrigation activities than distant water sources. On the contrary, those distant from water sources are not interested to participate in irrigation works. The odds ratio of 1.07 indicates that with the assumption of Ceteris paribus, agro-pastoralist who has access to irrigation water is more likely to participate than non-access to irrigation water by a factor of 1.07.

Extension contact (Frequency): This variable is significant at less than $5 \%$ level and related positively to participation in irrigation activities. As the frequency of the average contact with extension agents increases the participation of agro-pastoralists in irrigation activities increases. Agro pastoralists' experience on extension contact and access to updated information leads to the probability of adopting new technology since they can use the resources wisely with proper management of input for better production and productivity of high-value crops. The odds ratio of 7.43 indicates that with the assumption of Ceteris paribus, agropastoralists who frequently contact extension agents and get new information concerning irrigation use and input for better products are more likely to participate than non-access to irrigation water by a factor of 1.07. This study is consistent with the study of (Anwar, 2014; Kidanemariam, 2017) which indicated a positive relationship between frequency of extension contact and participation in irrigation, and also beneficiaries require advisory and other services to actively participate in irrigation. 
Table 6. Binary logistic model estimates.

\begin{tabular}{|lcccc|}
\hline Variables & Coef. & Odds ratio & Std.Err. & $\mathrm{P}>|\mathrm{z}|$ \\
\hline Age & $-0.47^{* *}$ & 0.626 & 0.128 & 0.022 \\
\hline Education & 0.08 & 1.088 & 0.281 & 0.744 \\
\hline Land size & -0.02 & 0.9784 & 0.740 & 0.977 \\
\hline Labour force & $1.88^{* *}$ & 6.581 & 5.408 & 0.022 \\
\hline Extension contact & $7.43^{* *}$ & 1689.200 & 5787.700 & 0.030 \\
\hline Access to irrigation & $0.23^{* *}$ & 1.256 & 0.120 & 0.018 \\
\hline Non-farm inc & -0.09 & 0.914 & 0.067 & 0.220 \\
\hline Credit access & $0.01^{* *}$ & 1.007 & 0.003 & 0.049 \\
\hline Livestock holding & -0.08 & 0.923 & 0.065 & 0.260 \\
\hline Constant & 2.97 & 19.451 & 76.487 & 0.450 \\
\hline
\end{tabular}

Source: Model output

**Denotes $0.01>p<0.05 ;$ Number of Obs $=120$, LR Chi $^{2}(9)=41.01$, Prob $>$ Chi $^{2}=0.0000$ Pseudo $R^{2} \quad=$ o.6415, Log likelihood $=-11.460452$

\section{Conclusions and Recommendations}

The development of irrigated agriculture has for long been seen as a means to break the cycle of poverty in Ethiopia. It can increase production and returns, protects against risks of crop loss due to deficient rainwater provisions, encourages the use of yield-enhancing farm inputs, and create extra employment options. These may support very poor households to meet their basic needs by improving their overall economic livelihood status that in the long run allows them to change out of the deficiency deception. In the study area income from crop and livestock sales in irrigation, using area over non-using agropastoralists is far higher due to the number of cropping per year and diversification of crop production. Thus, the development of irrigation access to this area increases the of use untapped water and land resources in the area.

The logistic regression model revealed that age, credit access, extension contact, distance to water, and labour force significantly affected the decision of a given agro-pastoralists to participate in irrigation practices at less than $5 \%$ probability levels. This indicates that the explanatory variables, which are included in the model, have influences on the decision of agro-pastoralists to participate in irrigation practices. Therefore, the provision of credit service to allow rapid progress in the introduction of technologies like a tractor for farming practices, frequent extension contact with irrigation users could enhance the productivity in the area.

\section{Conflict of interest}

The authors declared that they have no conflict of interest.

\section{Acknowledgments}

The authors acknowledged Southern Agricultural Research Institute, Jinka Agricultural Research Center for financial support.

\section{References}

Amede, T. 2006. Improving drought resistance of grain legumes in Ethiopia: Aphysiological approach. pp. 185-190. In: Ali, K., Kenneni,G., Ahmed, S., et al. (Eds). Food and forage legumes of Ethiopia: Progress and prospects. International Centre for Agricultural Research in the Dry Areas (ICARDA), Aleppo, Syria.

Amede, T. and Haileslassie, A. 2011. Agricultural water management systems in the context of climate change in SSA. In: Strengthening capacity for climate change adaptation in the agricultural sector in Ethiopia. Proceedings from National Workshop. FAO Environment and Natural resources management, Rome, working paper 48, pp. 33-46.

Anwar, A. 2014. Impact of small-scale irrigation on household welfare case of Laelay Dayu Irrigation Scheme, Alamata district, Tigray: MSc Thesis, Mekele University, Ethiopia. 104p.

Asmera, A. and Melkamu, M. 2020. Agro Pastoralist's Perception and Willingness to Participate in Water Harvesting Practices in South Omo Zone, Southern Ethiopia. American J. Agric. Forest. 8(5): 223-234. https://doi.org/10.11648/j.ajaf.20200805.16

Asmera, A., Mekete, G., Dawit, D. and Kutoya, K. 2020. Value chain analysis of goat in South Omo Zone, SNNPR, Ethiopia. J. Agril. Econ. Res. Dev. 7(1): 907-919.

Astatike, A.A. 2016. Assessing the impact of small-scale irrigation schemes on household income in Bahir Dar Zuria Woreda. J. Econ. Sust. Dev. 7(21): 85 .

Awulachew, S.B. and Ayana, M. 2011. Performance of irrigation: An assessment at different scales in Ethiopia. Exp. Agric. 47(S1): 57-69.

https://doi.org/10.1017/So014479710000955 
Awulachew, S.B., Erkossa, T. and Namara, R.E. 2010. Irrigation potential in Ethiopia. Constraints and opportunities for enhancing the system. Addis Ababa, Ethiopia: International Water Management Institute. pp. 22-23.

Berehanu, E. 2007. Livelihood strategies of smallholder farmers and income poverty in drought prone areas: the case of Gena-Bosa woreda, SNNPRS. MSc thesis, School of Graduate Studies of Haromaya University. $38 \mathrm{p}$.

Bewket, W. 2007. Rainfall variability and agricultural vulnerability in the Amhara Region, Ethiopia. Ethiopian J. Dev. Res. 29(1): 1-34.

https://doi.org/10.4314/ejdr.v29i1.38642

Danso, G.K., Drechsel, P., Akinbolu, S.S. and Gyiele, L.A. 2003. Review of studies and literature on the profitability and sustainability of urban and peri-urban agriculture. FAO Final Report (PR 25314), IWMI, Accra.

Faruqui, N.I., Niang, S. and Redwood, M. 2004.Untreated wastewater use in market gardens; a case study of Dakar, Senegal. In: Wastewater Use in Irrigated Agriculture:Confronting the Livelihood and Environmental Realities, ed. C. Scott, N.I.Faruqui, L. Raschid. Wallingford: IWMIIDRC-CABI. pp. 113-125. https://doi.org/10.1079/9780851998237.0113

García-Bolanos, M., Borgia, C., Poblador, N., Dia, M., Seyid, O.M.V. and Mateos, L. 2011. Performance assessment of small irrigation schemes along the Mauritanian banks of the Senegal River. Agril. Water Manage. 98: 1141-1152.

https://doi.org/10.1016/j.agwat.2011.02.008

Gebrehiwot, K.G., Makina, D. and Woldu, T. 2017. The impact of micro-irrigation on households' welfare in the northern part of Ethiopia: An endogenous switching regression approach. Stud. Agril. Econ. 119(3): 160-167. https://doi.org/10.7896/j.1707

Gujarati, D.N. 2003. Basic Econometrics $\left(4^{\text {th }}\right.$ ed.).New York: The McGraw-Hill, Inc. 595$607 \mathrm{p}$.

Kidanemariam, G.G. 2017. The impact of microirrigation on households' welfare in the northern part of Ethiopia: an endogenous switching regression approach. Stud. Agril. Econ. 119: 160-167.

https://doi.org/10.7896/j.1707

Makombe, G.,Namara, R., Hagos, F., Awulachew, S.B., Ayana, M. and Bossio, D. 2011. A comparative analysis of the technical efficiency of rain-fed and smallholder irrigation in Ethiopia. International Water
Management Institute, Colombo, Sri Lanka. 37p. (IWMI Working Paper 143).

https://doi.org/10.5337/2011.202

MoA. 2011. Small-scale irrigation capacitybuilding strategy for Ethiopia. Natural Resource Management Directorate, Addis Ababa, Ethiopia. pp. 1-30.

Nhundu, K., Gwata, C. and Mushunje, A. 2010. Impacts of Zimbabwe European Union micro-project programme (Zim/Eu MPP) in funding smallholder irrigation projects on food security and income levels: A case study of Mopane irrigation scheme in Zvishavane, Midlands province, Zimbabwe. African $J$. Agril. Res. 5(14): 1759-1771.

OIDA. 2004. Strategic Planning and Management Document, Finfine. Oromia Irrigation Development Authority, Ethiopia. pp. 3-19.

http://open_jicareport.jica.go.jp/pdf/11688033. pdf

Owusu, E.S., Namara, R.E. and Kuwornu, J.K. 2011. The welfare-enhancing role of irrigation in farm households in northern Ghana. J. Int. Diver. 1: 61-87.

Regassa, A.E. 2015. Determinants of agropastoralists participation in irrigation scheme: The case of Fentalle agro-pastoral district, Oromia regional state, Ethiopia. Int. J. Agril. Res. Innov. Tech. 5(2): 44-50. https://doi.org/10.3329/ijarit.v5i2.26269

Seleshi, B., Merrey, D.J., Kamara, A.B., Van Koppen, B., Penning de Vries, F. and Boelee, E. 2005. Experiences and opportunities for promoting small-scale/micro irrigation and rainwater harvesting for food security in Ethiopia. Colombo, Sri Lanka: IWMI. V. 86p. (Working Paper 98).

Terefe, A., Ebro, A. and Zewedu, T. 2010. Rangeland dynamics in South Omo Zone of Southern Ethiopia: Assessment ofrangeland condition in relation to altitude and Grazing type. Liv. Res. Res. Dev. 22(10): 1-12.

UNDP. 2016. African economic outlook: Ethiopia. 3p. www.africaneconomicoutlook.org

WAIPRO. 2009. Improving food security in West Africa through revitalizing irrigation systems performance and productivity and promotion of agricultural water and smallscale irrigation. Project Document. West African Irrigation Project, International Water Management Institute (IWMI), Colombo, Sri Lanka. p. 19.

Yeshambel, Y. 2019. Impact of Small Scale Irrigation Schemes on household Welfare: The Case of Mecha District, Ethiopia. Master's thesis. Bahir Dar University, Bahir Dar, Ethiopia. 58p. 